\title{
Rating of Physics Laboratory Resources Management in Tertiary Institutions: Implications for Teaching and Learning STEM Subjects
}

\author{
Abiodun Bada1, Loyiso Jita ${ }^{2}$ \\ 1,2 Faculty of Education, School of Natural Science and Technology Education, University of the Free State \\ (RSA), South Africa
}

\begin{abstract}
Physics, a major branch of science, requires adequate implementation of its theoretical and practical components. The critical role of the laboratory in realizing this goal cannot be overemphasized hence, the need for proper management of laboratory resources. This study investigated the rating of physics laboratory resources management in tertiary institutions and its implications for STEM subjects using students' voices. The investigation adopted a descriptivesurvey research design which comprised 596 students taking physics-related courses in six tertiary institutions in Ondo State. A questionnaire with 19 item statements was designed titled 'Questionnaire on Physics Laboratory Resources Management' (QPLRM) and used to collect data for this study. The data collected were analysed using mean scores and ranking. Inadequate funding to carry out managerial plans and lackadaisical attitude on the part of lecturers were rated highest to have hindered the proper management of physics laboratory resources for improving STEM subjects. The study concludes that adequate funding and improved positive attitude on the part of lecturers and support staff are important to guarantee proper teaching of STEM subjects. The study recommends that the government, through its agencies, should provide more funds for the adequate implementation of STEM subjects.
\end{abstract}

Keywords: Physics laboratory resources management, Learning, Rating, STEM, Teaching

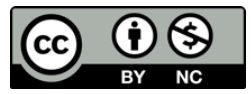

This is an open access article under the CC-BY-NC license.

\section{INTRODUCTION}

As a subject, physics is an important aspect of science that relies greatly on practical work (practicals). It is an essential component that is taught at the senior secondary and tertiary levels of education in Nigeria. Since the proper teaching of physics depends greatly on practicals, there is a need to look into the proper management of physics laboratories at the secondary school level and, most importantly, at the tertiary institutions in Nigeria. This is because graduates of physics-related disciplines need to be properly grounded in the subject matter so as to ensure professionalism in the discharge of their duties, especially as it relates to science, technology, engineering, and mathematics (STEM) education. Physics is the study of matter, energy, and its interactions (Omosewo, 2001). The importance of physics to nation-building has been stressed in different fora, especially towards the realization of the philosophy of education in Nigeria. Regarding tertiary education in Nigeria, the National Policy on Education (Federal Republic of Nigeria [FRN], 2013) has, among other objectives, the objective that tertiary education should contribute to national development through high-level workforce training. This objective might remain a mirage if the necessary steps that could guarantee proper teaching of the subject are not treated with all the importance it deserves.

Physics is an essential subject that contributes to the successful implementation of STEM education in Nigeria. In Nigeria, physics forms one of the compulsory subjects students need to pass with at least a credit pass at the secondary level of education before students can gain admission to study STEMrelated courses at tertiary institutions (FRN, 2013). The need for the proper teaching and learning of physics, therefore, cannot be overemphasized. Therefore, it is important to pay more attention to the use of its laboratory and how the resources are being managed to help improve the teaching and learning of the subject. 
Ebirim and Ochai (2011) define resources as all humans, finances, and materials available in the organization or institution which are used as input in production. Resources are seen as those inputs that can help guarantee the required results. This emphasizes the fact that adequate resources can help in achieving the objectives of the teaching-learning process. These resources are usually kept and used in the laboratory; hence, the importance of a laboratory to the proper study of not only physics but science education in general.

A laboratory is a place where scientific investigations are carried out. Akinbobola and Author (2017) view a laboratory as a place where problems are created and solutions are also generated. The importance of the laboratory and its management to the study of physics and other STEM subjects becomes imperative because of the sensitive height it occupies to ensure that teaching science goals are met.

Laboratory management is the proper planning, development, and utilisation of human and nonhuman resources in order to provide a conducive environment that can prevent accidental injuries (Akinbobola, 2015). In the words of Oyekan, Asaaju, and Obe (2017), laboratory management is the adoption of appropriate human and material resources to ensure a safe and healthy environment that prevents injuries or accidents to those in the laboratory. As with other sciences, the study of physics requires that the resources to be used should ensure that students are not exposed to accidental injuries. Armstrong (2006) thus views the management of resources as the process of setting and achieving goals through the execution of planning, organising, staffing, directing and controlling the utilisation of human, material, and capital resources.

Good laboratory management begins with the design of the laboratory because a laboratory is described as a place where scientific investigation or research is carried out. A good physics laboratory must be at least $89.2 \mathrm{~m}^{2}$ with a demonstration bench of about $0.23 \mathrm{~m}$ high. It must have a preparatory room of about $21.37 \mathrm{~m}^{2}$ and a store. Akinbobola and Author (2017) have identified some importance of the physics laboratory: This includes:

i. The laboratory is the source of problems for students to solve;

ii. The laboratory provides for the solutions to problems students encounter in the laboratory, classroom, or elsewhere;

iii. The laboratory gives room for critical reasoning and generation of ideas in physics;

iv. The laboratory provides for illustration of phenomena, principles, and applications that provide means to verify facts, laws, and generalisation;

v. The laboratory contributes to students' knowledge and understanding of facts, laws, principles, and concepts;

vi. The laboratory contributes to the development of scientific knowledge, skills, and attitudes.

Since all the resources for teaching physics are kept in the laboratory, there is a need to properly manage these resources. The adequate use, proper use, and management of the laboratory might have the capacity to enhance concept formation and remove misconceptions to facilitate meaningful learning of physics and STEM subjects at large. This study has two objectives (i) to investigate how physics students rate the management of physics laboratory resources in tertiary institutions (ii) to investigate the strategies that can be used to improve the management of physics laboratory resources for STEM education. 


\section{Purpose of the Study}

The main purpose of this study is to rate physics laboratory resources management in tertiary institutions and its implications for teaching and learning STEM subjects. Specifically, this study found out:

i. how physics students rate the management of physics laboratory resources in tertiary institutions.

ii. How physics students rate the strategies suggested for improving the management of physics laboratory resources for teaching and learning STEM subjects.

\section{Research Question}

The following research questions were raised to guide this study.

1. How do physics students rate physics laboratory resources management in tertiary institutions?

2. How do physics students rate the strategies that can be used to improve the management of physics laboratory resources for teaching and learning STEM?

\section{LITERATURE REVIEW}

According to Sauders (2009), the acronym STEM was first coined many decades ago by the National Science Foundation (NSF). American NSF researcher Judith Ramaley first used STEM as a term. Its teaching in Nigeria began in the year 1859 in CMS Grammar School, Lagos, and was limited to the teaching of arithmetic, algebra, geometry, etc philosophy (Ugo \& Akpoghol, 2016). This was closely followed by the constitution of different science-curricula development committees such as the Phelps-Stokes Education Commission, Comparative Education Study and Adaptation Centre (CESAC), and the Science Teachers Association of Nigeria (STAN), to mention a few.

STEM is an abbreviation that comes from four closely related and connected areas of study - science, technology, engineering, and mathematics (Stokdyk, 2016). This abbreviation is relatively new because Badmus and Omosewo (2020) opine that STEM was formerly referred to as Science, Technology, and Society (STS). The National Inventors Hall of Fame (2021) define STEM education as an inter-related disciplinary method to learning. Through this method, major academic concepts are combined with real-life-situation lessons to the way students apply STEM disciplines. These ways ensure inter-relation among schools, communities, workplaces, and the entire world. This subsequently gives rise to the development of STEM literacy. Morrison (2006) defines STEM as an interdisciplinary method to learning where several science and technology subject disciplines are taught by integrating mathematics and engineering into the curriculum such that it represents a shift from the conventional teacher-centered classroom. Ubawuike (2018) defines STEM as a metadiscipline that came to light as a result of other areas to bridge gaps over several subject areas.

Science, the first word that makes up STEM is defined as any system of knowledge that is concerned with the physical environment and its occurrences, which also involves factual observations and systematic experimentation (Britannica, 2020). It is the investigation of natural occurrences through careful observations, theoretical explanation, and experimentation of the knowledge derived from such findings.

The second letter in STEM was taken from the word Technology. According to Volti (2009), he defines technology to mean the techniques, methods, and processes used to produce the products of science, which includes accomplishing objectives to meet the needs of society. Technology has to do with modifications of the environment to satisfy society's needs and aspirations. Volti (2009) defines technology as a system created by humans who use knowledge and organization to produce objects 
and techniques for the attainment of specific goals. When said goals are achieved through knowledge and organization, this can be referred to as the science behind the goals having been successfully implemented. Some of these goals include the designing and producing of devices such as televisions, laptops, and phones.

Engineering stands as the third word whose first letterforms an integral part of the acronym, STEM. Engineering is the application of science to the maximum conversion of the resources of nature to products that can be used by humankind (Smith, 2020). Engineering deals with the utilisation of scientific principles to design materials and devices that tend to make life more meaningful for humankind to be useful in society. It is the careful application of science and mathematics to solve identified problems.

Last but not least, Mathematics, as another integral part of STEM, is the science of structure, order, and relation derived from basic practices like counting, measuring, and explaining the shapes of objects. Mathematics is the study of measurement, relationship, and properties of quantities and sets using numbers and symbols, which is also referred to as the science of logic of shape, quantity, and arrangement. Dictionary.com (n.d.) defines mathematics as operations and processes that help in providing solutions to problems related to the scientific field. This suggests that knowledge of mathematics is important in studying science.

STEM education is important in almost all countries over the world because its indices are usually used in rating nations (National Research Council, 2012). The National Research Council (2011) views STEM education as the tendency to encourage inter-disciplinary knowledge and skills relevant to living a good life, especially in the K-12 educational setting. STEM education also can elevate the current generation's mindset to be more innovative (Corlu, Capraro \& Capraro, 2014). In the study carried out by Brown, Brown, Reardon, and Merrill (2011) on whether STEM education is important, the researchers found that STEM education is a way to bridge disciplines, provide cognitive building blocks for students, and teach the needed skills. The researchers are also of the opinion that STEM education has a role to play in teaching problem-solving.

In their research on the importance of STEM education in the elementary grades according to preservice and novice teachers' perspectives, Madden, Beyer, and O'Brien (2016) indicate that all the participants agreed that STEM education was important at the elementary level. This is because STEM is the foundation of later studies, connects to everyday life, nurtures positive STEM attitudes, integrates or balances contents, and prepares students for jobs. In addition, STEM promotes learning or higher-order thinking, allows for the development and spread of technology, promotes hands-on inquiry or design, promotes gender equity in STEM fields of work, and maintains global competitiveness in the world of scientific discovery.

In Nigeria, STEM education is an important topic because it occupies a high position in ensuring the development of the nation (Adeyemo, 2010). The laboratory has been found as a crucial place for the learning of STEM because it is a place where problems are created and solutions generated. Okeke and Chinwe (2006) therefore opine that the learning of STEM must start and end in the laboratory. This suggests that the laboratory plays a major role in the realisation of STEM objectives. Hence, there is a need to pay more attention to STEM resources management in all levels of education and, most especially in tertiary institutions, which are the scope of this study. Oriafo (2002) carried out research on refocusing science, technology, and mathematics education in Nigeria. He argued that STEM education is grossly affected by content inadequacy; poor teaching methods by teachers; dominating 
cultural lapses; and paucity of facilities, equipment, and materials in the laboratory. His findings also emphasize the prominent role the laboratory plays in the achievement of STEM goals.

Brown et al. (2011) conducted research on understanding STEM and its current perceptions by students in STEM education and leadership program at Illinois State University. The researchers discovered that STEM education is not well understood by administrators of teachers doing a STEMfocused master's degree and that there is a need to increase awareness at both administrator and student levels. The researchers also suggest that there is no clear vision for STEM education, even among those who believe in its importance. Hence, there is a need for raising awareness and defining STEM and how STEM education should be implemented. Brown et al. (2011) conclude that there was little evidence that STEM education existed in the schools surveyed based on the lack of existing collaboration that should exist among schools.

Ugwu, Nwokocha, and Ozioko (2011) investigated teachers' position in the reform of STEM education in Nigeria. The researchers emphasize the crucial role teachers' play in the successful implementation of STEM education. They conclude that STEM teachers in Nigeria are rarely involved in the process of curriculum development and reforms, which might be why these teachers show reluctance towards implementing any reform connected with STEM education. The position the teacher occupies in the realization of teaching and learning objectives has been clearly stressed, as no nation can develop further than the quality of its teachers (FRN, 2013).

Nwagbo and Ukaegbu (2012) carried out research on biology laboratory resource management in colleges of education in Nigeria and its implications for universal basic education (UBE). The researchers found that lack of funds to carry out management plans, lack of supervision of resources, and excessive use of available staff and materials are some of the factors militating against the effective management of resources in the country's colleges of education. The researchers also discovered that proper supervision of resources and materials, documentation of funds, and logistics of resources are some of the strategies that can be adopted to improve the management of resources for UBE programs. Corlu et al. (2014) carried out an investigation into the implications of educating teachers for the age of innovation through the introduction of STEM education in Turkey. The researchers emphasize the importance of integrated teaching knowledge as teacher knowledge varies with the school type, school level, and teacher characteristics. They propose a STEM education model with particular reference to mathematics and science. The researchers submit that integrated teacher education programs may prepare pre-service teachers with the skills to implement reforms, thus making the teacher the driving force behind and a genuine supporter of reforms.

Madden et al. (2016) carried out an exploratory study on the structure of beliefs among prospective and novice teachers regarding the importance of STEM education. They found that STEM education is important at the elementary level because it lays a foundation for later courses. In addition, Ugo and Akpoghol (2016), in their study on improving STEM programs in secondary schools in Benue State, Nigeria, identify poor teaching qualification, lack of improvisation, lack of cooperation, lack of basic laboratory reagents, and instructional methods as some of the challenges facing STEM education in Nigeria.

Famunyan (2019) conducted research into the challenges of teaching STEM in Nigeria. The researcher discovered various challenges being faced by STEM education in the country. These include inadequate facilities such as standard laboratories, lack of educational infrastructures, imbalance in the school curriculum, continuous gap between Nigerian students and their international peers, lack 
of digitalisation of education, brain drain and gain to developed countries, corruption in the educational setting, low salaries and lack of incentives for teachers.

Umar (2019) investigated STEM education as a catalyst for national development. The researcher probed into the problems and prospects of STEM education in Nigeria and found that class size, teacher factor, teaching method, language, resource utilisation, and workload are factors hindering the successful implementation of STEM education. The researcher also identified innovative teaching methods, the establishment of more technical colleges and universities, and the provision of science equipment and laboratories to improve STEM education in Nigeria.

The reviewed literature emphasizes the importance of the laboratory, among other factors, in the successful implementation of STEM education in Nigeria (Omosewo,2006; Adeyemo, 2010; Nwagbo \& Ukaegbu, 2012; Famunyan, 2019). Omosewo (2006) emphasized the importance and effectiveness of the laboratory method as a method that can be used to better student science-based disciplines. This buttresses the fact that special attention should be placed on how the resources in the laboratory are being managed to ensure the realization of set objectives in STEM education. Rating is an aspect of evaluation, and this has always being left in the hands of teachers, directors of school units and municipality technical service assistants, head of schools, departments and programs, school stakeholders, and approved government agencies, with little or no desired results achieved (Baltas \& Consultant, 2005; Hasbullah, Yusoff, Ismail \& Vitasari, 2011; Limon, 2016).

Evaluation can also be left in the hands of the students, who are also important stakeholders in the business of teaching and learning. The voice of students as regards rating of school experiences can also go a long way in giving a clear picture of the situation. This assertion is supported by Aladejana and Aderibigbe (2007) and Omiko (2015), who gave students the voice to access school facilities and various components of the science laboratory in their different studies. The reviewed literature revealed that little or no studies had been conducted on the management of physics laboratory resources with implications for teaching STEM subjects in Ondo, Nigeria. Literature also showed that only one related study was conducted on laboratory resource management, even though it was on biology (Nwagbo \& Ukaegbu (2012). Despite the fact that the study by Nwagbo and Ukaegbu (2012) was carried out in Nigeria, the investigation into laboratory resources management was not viewed using the students as a lens to unpack its implication for STEM subjects but rather it was on universal basic education (UBE). Therefore, the present study leveraged students' voices to investigate the management of physics laboratory resources in tertiary institutions. It also used the findings from the study to infer implications for the teaching of STEM subjects.

\section{RESEARCH METHOD}

This study adopted a descriptive-survey research design. A descriptive study is used to describe the distribution of one or more variables without taking into consideration any cause or hypothesis (Aggarwal \& Ranganathan, 2019). The method used in this investigation was discussed under the following headings: participants, instrument, the procedure for data collection, and the data analysis technique.

\section{Participants}

The population for the study comprised all the tertiary institutions in Ondo State, Nigeria. There are 10 tertiary institutions in Ondo State, and out of this number, the purposive sampling technique was used to select two institutions, each from the three senatorial districts of Ondo State. A simple random technique was used to select 596 students who took a major course in physics in the year under review. Efforts were made to ensure that only students in the penultimate year of study were used in the study because it was assumed that these students would have been exposed to most of the 
laboratory resources for teaching the different physics components and also aware of the management of these resources. It was also assumed that students would be able to suggest how the successful implementation of the management of these resources can affect the teaching and learning of STEM education. The demographic information of the participants is shown in Figure 1.

\section{Instrument}

A researcher designed a questionnaire titled 'Questionnaire on Physics Laboratory Resources Management' (QPLRM) and used to obtain data for this study. The items that make up the questionnaire were compiled from an initial survey on the management of physics laboratory resources for teaching physics. Twenty-three students who were not part of the study were initially interviewed using a semi-structured questionnaire on the management of physics laboratories in tertiary institutions. The responses of the respondents were audiotaped and recorded. The researchers later transcribed the recorded data in order to have an idea of those components that should form part of the questionnaire. The draft from the transcribed data was used to collect data for this study, and it was divided into two sections. Section A requests the participants' demographic data, whereas Section B consists of 19 statements on the management of physics laboratory resources. Response types for Section B were Strongly Agree (SA), Agree (A), Disagree (D), and Strongly Disagree (SD). QPLRM was validated by two experts in the Department of Curriculum and Instruction and three lecturers in the Department of Physics at Adeyemi College of Education, Ondo State, Nigeria. The comments of the validators on the content and structure of the instrument were duly corrected. The reliability of the QPLRM was achieved by trial testing it on a sample of 45 students in one other tertiary institution who was not part of the sample used in this study. A reliability coefficient index of 0.78 was obtained using Cronbach's alpha. This achieved index of 0.78 showed that the instrument is consistent enough to measure what it was designed to measure.

\section{Procedure for Data Collection}

The researchers sought the consent of the selected institutions' administrators to use their students as participants for this study. The researchers also sought the permission of the students to take part in this study. Only those who indicated a willingness and gave consent to take part in the study were used for this study. After due permission had been given by the institutions and the consent of the students received, copies of QPLRM were administered to the participants with the help of five research assistants. The research assistants assisted with the administration of the instruments in order to give them wider coverage. Students completed the questionnaires, and the research assistants and the researchers immediately retrieved it. The administration of the questionnaire was done over a period of four weeks.

\section{Data Analysis Technique}

The data collected were analysed using descriptive statistics. We used the Microsoft Excel spreadsheet package to compute the data obtained from this study. The two research questions were answered using mean. Participants responded to the questionnaire, and their responses were analysed using the following grading system: Strongly Agree $(S A)=4$, Agree $(A)=3$, Disagree $(D)=2$, Strongly Disagree $(\mathrm{SD})=1$. For the decision rule, an average mean value (AMV) less than 22.0 implies that the management of physics laboratory resources was rated low by the students, while an average mean value equal to or greater than 22.0 implies that the management of physics laboratory resources was rated high by the students. For research question 2, an average mean gain less than 16.0 implies that the strategies that can be used to improve the management of physics laboratory resources for teaching and learning STEM were rated low, while an average mean value (AMV) equal to or greater than 16.0 implies that the strategies that can be used to improve the management of physics laboratory resources for teaching and learning STEM were rated high by the students. 


\section{RESULTS AND DISCUSSION}

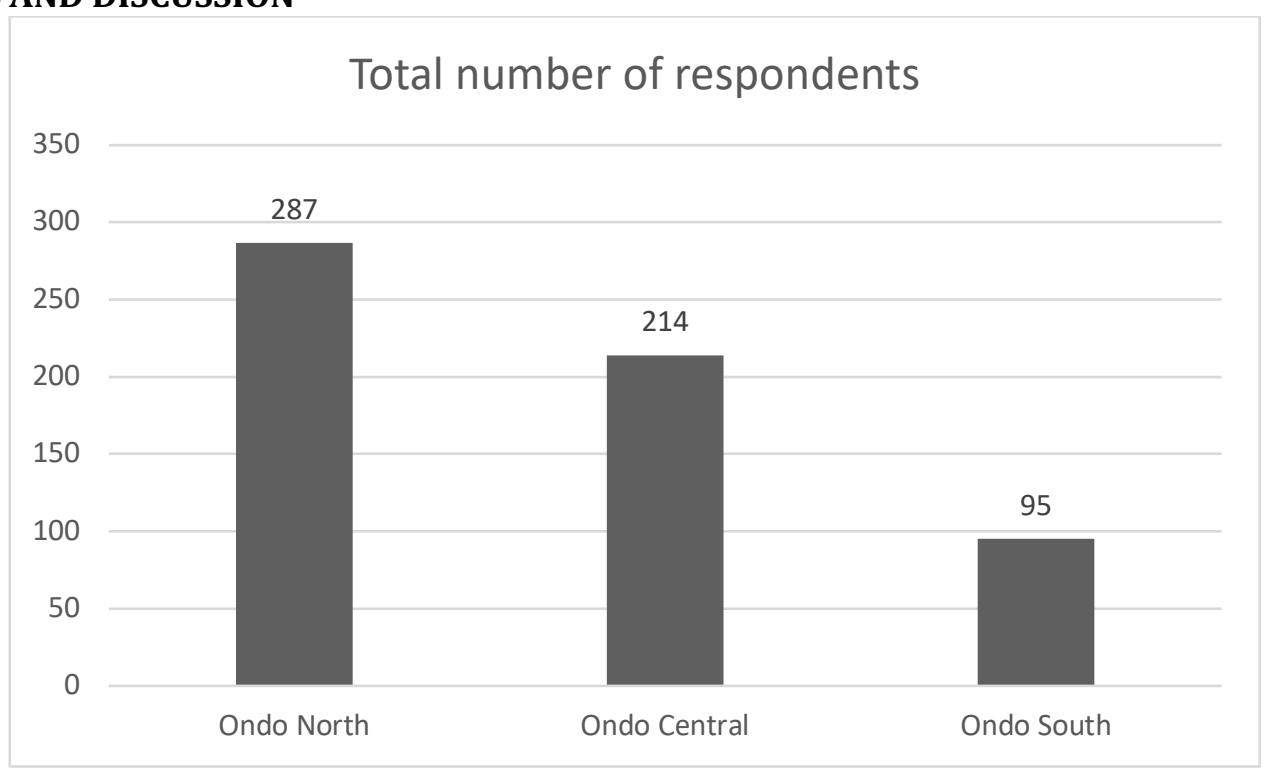

Figure 1: Demographic information of respondents by senatorial district

As seen in Figure 1, 214 of the respondents were from Ondo Central senatorial district, 95 were from Ondo South senatorial district, and 287 were from Ondo North senatorial district. A total of 596 respondents took part in this study. In this section, each research question and its related findings are discussed.

Research Question 1: How do physics students rate physics laboratory resources management in tertiary institutions?

Table 1. Physics laboratory resources management

\begin{tabular}{|l|l|l|l|}
\hline Statement on physics laboratory resources management & Mean & Decision & Rank \\
\hline Inadequate funding to carry out managerial plans & 2.54 & SA & $1^{\text {st }}$ \\
\hline Inadequate supply of human and material resources & 2.40 & SA & $3^{\text {rd }}$ \\
\hline Poor supervision of physics laboratory resources & 2.32 & SA & $5^{\text {th }}$ \\
\hline Too large coursework for lecturers to teach and handle & 2.34 & SA & $4^{\text {th }}$ \\
\hline Poor record-keeping of activities in the laboratory & 2.31 & SA & $6^{\text {th }}$ \\
\hline $\begin{array}{l}\text { Constant and timely replacement of bad materials and resources } \\
\text { in the laboratory }\end{array}$ & 2.21 & $\mathrm{~A}$ & $1^{\text {th }}$ \\
\hline $\begin{array}{l}\text { Lackadaisical attitude on the part of lecturers and laboratory } \\
\text { support staff to managing materials and resources }\end{array}$ & 2.43 & SA & $2^{\text {td }}$ \\
\hline Ignorance on the proper use of materials and resources & 2.25 & SA & $8^{\text {th }}$ \\
\hline $\begin{array}{l}\text { Poor planning on the part of lecturers and laboratory support } \\
\text { staff }\end{array}$ & 2.23 & $\mathrm{~A}$ & $9^{\text {th }}$ \\
\hline Poor monitoring strategies on the part of lecturers & 2.20 & $\mathrm{~A}$ & $11^{\text {th }}$ \\
\hline Poor cooperation between lecturers and students & 2.28 & SA & $7^{\text {th }}$ \\
\hline $\begin{array}{l}\text { Average mean value (AMV) } \\
\text { Decision }\end{array}$ & 25.51 & &
\end{tabular}

Decision rule: $\mathrm{WMV}<22.00=$ Low; $\mathrm{WMV} \geq 22.00=$ High

As seen in Table 1, inadequate funding to carry out managerial plans was rated first, whereas lackadaisical attitude on the part of lecturers and laboratory support staff was ranked second. 
Inadequate supply of human and material resources was ranked third, while too large coursework for lecturers to teach was rated fourth. The statement rated fifth was poor supervision of physics laboratory resources, with poor record-keeping of activities in the laboratory ranked sixth. Participants rated poor cooperation between lecturers and students seventh, while ignorance on the proper use of materials and resources was rated eight. Furthermore, poor planning on the part of lecturers and laboratory support staff was rated ninth, while constant and timely replacement of bad materials and resources in the laboratory was rated tenth. The statement rated last $\left(11^{\text {th }}\right)$ was poor monitoring strategies on the part of lecturers.

This means that inadequate funding topped the list of factors affecting the proper management of physics laboratory resources and invariably has a negative effect on the proper administration of STEM education in Ondo State. This finding agrees with Nwagbo and Ukeagbu (2012), who found that a lack of funding to carry out managerial functions affects the proper implementation of UBE through proper management of biology laboratory resources. In summary, the management of physics laboratory resources was rated high because the average mean value (AMV) of 25.51 is greater than the AMV benchmark of 22.00 .

Research Question 2: How do physics students rate the strategies that can be used to improve the management of physics laboratory resources for teaching and learning STEM?

Table 2. Strategies to improve physics laboratory resources management

\begin{tabular}{|l|l|l|l|}
\hline $\begin{array}{l}\text { Strategies to improve physics laboratory resources } \\
\text { management }\end{array}$ & Mean & Decision & Rank \\
\hline $\begin{array}{l}\text { Adequate training of lecturers and laboratory support staff on } \\
\text { the need for proper management of laboratory resources }\end{array}$ & 3.54 & SA & $2^{\text {nd }}$ \\
\hline $\begin{array}{l}\text { Improved funding of laboratory resources to enhance } \\
\text { managerial plans }\end{array}$ & 3.86 & SA & $1^{\text {st }}$ \\
\hline $\begin{array}{l}\text { Constant evaluation of the effectiveness of physics laboratory } \\
\text { resources }\end{array}$ & 3.22 & SA & $6^{\text {th }}$ \\
\hline Keeping adequate records of activities in the laboratory & 3.41 & SA & $4^{\text {th }}$ \\
\hline Proper supervision of human and material resources & 3.26 & SA & $5^{\text {th }}$ \\
\hline Prompt repair and replacement of damaged resources & 3.42 & SA & $3^{\text {rd }}$ \\
\hline Proper monitoring of the use of resources and materials & 3.18 & $\mathrm{~A}$ & $7^{\text {th }}$ \\
\hline $\begin{array}{l}\text { Giving counseling to lecturers and laboratory support staff on } \\
\text { the need for proper management of physics laboratory } \\
\text { resources }\end{array}$ & & $\mathrm{A}$ & $8^{\text {th }}$ \\
\hline Average & & \\
\hline
\end{tabular}

Average Mean Value (AMV)

26.75

Decision rule: $\mathrm{WMV}<16.00=$ Low $\mathrm{WMV} \geq 16.00=$ High

Table 2 reveals that participants rated improved funding of laboratory resources to enhance managerial plans as the first strategy that can be used to improve the management of physics laboratory resources for teaching and learning STEM. Adequate training of lecturers and students on the need for proper management of laboratory resources was rated second. Prompt repair and replacement of damaged resources for efficiency was rated third, while adequate keeping of records of activities in the laboratory was rated fourth. The strategy rated fifth was proper supervision of human and material resources, with constant evaluation of physics laboratory resources rated sixth. Participants rated proper monitoring of the use of resources and materials as the seventh strategy, 
and staff and student counseling on the need for proper management of physics laboratory resources as the eight.

The findings from this study show that improved funding for physics laboratory management was ranked first as one of the strategies that can be adopted in eliciting the desired results for STEM education. Conversely, giving lecturers and laboratory support staff counseling on the need for proper management of physics laboratory resources was ranked last. In summary, strategies that can be used to improve the management of physics laboratory resources for teaching and learning STEM were rated high because the average mean value (AMV) of 26.75 is above the AMV benchmark of 16.00 .

\section{Implications of the Findings for STEM Education}

The findings of this study showed that inadequate funding to carry out managerial plans, lackadaisical attitude on the part of lecturers and laboratory support staff to managing materials and resources, and inadequate supply of human and material resources are the top three factors that militate against the effective management of physics laboratory resources. As such, improved funding, adequate training of lecturers and laboratory support staff on the need for proper management of laboratory resources, lecturers and support staff needing to have the right attitude, prompt repair and replacement of damaged resources, and keeping adequate records of activities in the laboratory are some of the means by which the objectives of STEM education can be achieved.

\section{Recommendations}

Based on the finding from this study, the following recommendations were considered appropriate:

1. Through its relevant agencies, the government should provide more funding for the management of physics laboratory resources in tertiary institutions, organise seminars and workshops for lecturers and laboratory support staff, and promptly repair and replace damaged resources in the laboratory.

2. Physics lecturers and support staff should develop a positive attitude towards the management of physics laboratory resources management and keep adequate records of activities in the laboratory.

\section{REFERENCES}

Adeyemo, S. A. (2010). Teaching and learning of physics in Nigerian secondary schools: The curriculum transformation, issues, problems, and prospects. International Journal of Educational Research and Technology, 1(4), 99-111.

Aggarwal, R., \& Ranaganathan, P. (2019). Study designs: Part 2- Descriptive studies. Perspectives in Clinical Research, 10(1), 34-36. https://doi.org/10.4103/picr.PICR_154_18

Akinbobola, A. O. (2015). Evaluating science laboratory classroom learning environment in Osun State of Nigeria. Journal of Resources, Development and Management, 9, 14-19.

Akinbobola, A. O., \& Author, (2017). Creative teaching of physics. In S. O. Oyekan, A.O. Akinbobola \& R.F. Adebile (eds). A compendium of teaching methods (pp. 221-263). Ondo: Patrick Ade Prints.

Aladejana, F., \& Aderibigbe, O. (2007). Science laboratory environment and academic performance. Journal of Science Education and Technology, 16(6), 500 -506.

Armstrong, M. (2006). Human resource management practice. London: Kogan Page. Available at http//www.bartleby.com/65/x-/x-[personne.html

Badmus, O. T., \& Omosewo, E. O. (2020). Evolution of STEM, STEAM and STREAM education in Africa: The implication of the knowledge gap. International Journal of Research in STEM Education, 2(2), 99-106.

Baltas, E., \& Consultant, G. (2005). Evaluation of school building indices quality system in Greece. Evaluating Quality in Educational Facilities, 101 -114. 
Britannica, The Editors of Encyclopaedia (2020). Science. Encyclopaedia Britannica. Available at https://www.britannica.com/science/science.

Brown, R., Brown, J., Reardon, K., \& Merrill, C. (2011). Understanding STEM: Current perceptions. Technology and Engineering Teachers, 5-10.

Corlu, M. S., Capraro, R. M., \& Capraro, M. M. (2014). Introducing STEM education: Implications for educating our teachers for the age of innovation. Education and Science, 39(171), 74-85.

Dictionary.com (n.d.). Mathematics. Available at dictionary.com/browse/mathematics.

Ebirim, U., \& Ochai, G. 0. (2011). Managing family financial resources in a period of economic meltdown. International Journal of Educational Research, 11(1), 39-47.

Famunyan, K. G. (2019). Teaching STEM education in Nigeria: Challenges and recommendations. International Journal of Mechanical Engineering and Technology, 10(12), 85-93.

Federal Republic of Nigeria (FRN) (2013). National Policy on Education. Lagos: NERDC Press.

Hasbullah, A., Yusoff, W. Z. W., Ismail, M., \& Vitasari, P. (2011). A framework study of school facilities performance in public primary schools of Batubara district in Indonesia. Procedia Social and Behavioural Sciences, 15, 3708 - 3712.

Limon, M. R. (2016). The effect of the adequacy of school facilities on students' performance in technology and livelihood education. International Journal of Academic Research in Progressive Education and Development, 5(1). https://doi.org/10.6007/IJARPED/v5-i1/2060

Madden, L., Beyer, J., \& O'Brien, L. (2016). The importance of STEM education in the elementary grades: Learning from pre-service and novice teachers' perspectives. Electronic Journal of Science Education, 20(5), 1-18.

Morrison, J. (2006). TIES STEM education monograph series: Attributes of STEM education. Baltimore, MD: TIES. Available at http://www.leadingpbl.org/f/Jans\%20pdf\%20Attributes_of_STEM_Education-1.pdf

National Research Council (2011). Successful K-12 STEM education: Identifying effective approaches in science, technology, engineering and mathematics. Washington DC: National Academy Press.

National Research Council (2012). A framework for K-12 science education: Practices, crosscutting concepts, and idea. Washington, D.C. National Academies Press.

National Inventors Hall of Fame (2021). Why is STEM hard to define? Available at invent.org/blog/trends-stem/stem-define

Nwagbo, C. R., \& Ukaegbu, C. G. (2012). Biology laboratory resources management in colleges of education: Implication for universal basic education (UBE) programme. Proceedings of the 53rd Annual Conference of STAN, Author (pp. 253-259), 7 August 2012. Abuja: STAN Publications.

Okeke, U. A., \& Chinwe, E. N. (2006). Analysis of human resources for STEM instruction in Awka Educational Zone. Proceedings of the 47th Annual Conference of STAN, Anambra State (pp. 5861) 13 to 19 August 2006. Uyo: STAN Publications.

Omiko, A. (2015). Laboratory teaching: Implication on students' achievement in chemistry in secondary schools in Ebonyi State of Nigeria. Journal of Education and Practice, 6(30), 206 213.

Omosewo, E. O. (2001). In-service programme for senior physics teachers for improved teaching and assessment of students. Nigerian Journal of Development Issues: Education, Socio-Political and Economic Development, 5(1\&2), 200 - 219.

Omosewo, E. O. (2012). Laboratory teaching method in science-based disciplines. African Journal of Educational Studies, 4(12), 65-73.

Oriafo, S. O. (2002). Refocussing science technology and mathematics education in Nigeria: A book of readings. Agbor: Kmensuo Educational Publishers. 
Oyekan, S. O., Asaaju, O. A., \& Obe, O. A. (2017). Effective teaching of biology. In S. O. Oyekan, A. O. Akinbobola \& R. F. Adebile (eds). A compendium of teaching methods (pp. 121-157). Ondo, Patrick Ade Prints.

Sauders, M. (2009). STEM, STEM education, STEMmania. The Technology Teacher, 20-26. Available at https://vtechworks.lib.vt.edu/bitstream/handle/10919/51616/STEMmania.pdf?sequence

Smith, R. J. (2020). Engineering. Encyclopaedia Britannica. Available at www.britannica.com/science/mathematic

Stokdyk, D. (2016). What does STEM mean in education? Available at snhu.edu/aboutus/newsroom/2016/05/what-does-stem-mean-for-you

Ubawuike, A. B. (2018). Science, technology, engineering and mathematics (STEM) education: A catalyst for entrepreneurship and economic growth in Nigeria. International Journal of Education, Learning and Development, 7(1), 1-11.

Ugo, E. A., \& Akpoghol, T. V. (2016). Improving science, technology, engineering and mathematics (STEM) programmes in secondary schools in Benue State Nigeria: Challenges and prospects. Asian Pacific Journal of Education, Arts \& Sciences, 3(3), 6-16.

Ugwu, D. U., Nwokocha, C. O., \& Ozioko, S. U. (2011). Position of the teacher in the reform of STEM education in Nigeria. The Nigerian Journal of Research and Production, 19(1), 1-8.

Umar, Y. (2019). STEM education as a catalyst for national development: Problems and prospects in Nigeria. Learning Science and Mathematics, 14, 48-59.

Volti, R. (2009). Society and technological change. $7^{\text {th }}$ ed. New York: Routledge. 